\title{
HETEROGENEOUS PRESENTATION OF GIANT PROLACTINOMA
}

Lidia RADOMIR ${ }^{1}$, Adriana GOGOI ${ }^{1}$, Simona JERCALAU $^{1}$, Corin BADIU ${ }^{1,2}$

1 "CI Parhon" National Institute of Endocrinology, Bucharest, Romania

"Carol Davila" University of Medicine and Pharmacy, Bucharest, Romania

Background: Giant prolactinomas are relatively rare pituitary tumors, defined as adenomas greater than $4 \mathrm{~cm}$, with extrasellar extension, presenting with PRL levels $>1000 \mathrm{ng} / \mathrm{ml}$. Dopamine agonists (DA) are the first-line treatment. Most (90\%) of giant prolactinomas occur in men, presenting with a symmetric distribution with a peak during the forth decade of life. It appears that men are younger at diagnosis and with larger tumor size, not only due to a longer delay before diagnosis, but rather to an overall greater growth potential of prolactinoma in males.

Objectives and Methods: We reviewed two cases of giant prolactinoma in men to characterize clinical features and the response to DA therapy.

\begin{tabular}{|c|c|c|}
\hline & PATIENT 1 & PATIENT 2 \\
\hline Age at presentation & 17 years old & 27 years old \\
\hline $\begin{array}{l}\text { Duration of symptoms } \\
\text { prior to diagnosis }\end{array}$ & 2 months & 12 months \\
\hline Clinical presentation & $\begin{array}{l}\text { - frontal headache, } \\
\text { - visual deficit, } \\
\text { - nausea, } \\
\text { - dizziness. }\end{array}$ & $\begin{array}{l}\text { - fronto-occipital headache, } \\
\text { - weakness, } \\
\text { - recurrent posterior epistaxis, } \\
\text { - decreased libido. }\end{array}$ \\
\hline Initial PRL level & $19093 \mathrm{ng} / \mathrm{ml}$ & $31398 \mathrm{ng} / \mathrm{ml}$ \\
\hline $\begin{array}{l}\text { Maximum tumor diameter } \\
\text { at diagnosis }\end{array}$ & $6.4 / 3.4 \mathrm{~cm}$ & $6 / 5.6 / 4.3 \mathrm{~cm}$ \\
\hline DA therapy (maximal dose) & CBG $4.5 \mathrm{mg} /$ week & CBG $2.0 \mathrm{mg} /$ week \\
\hline Nadir PRL level & $1.18 \mathrm{ng} / \mathrm{ml}$ & $9.14 \mathrm{ng} / \mathrm{ml}$ \\
\hline $\begin{array}{l}\text { Tumor size at the last } \\
\text { evaluation }\end{array}$ & $1.9 / 1.2 \mathrm{~cm}$ & $4.8 / 4.6 / 4.5 \mathrm{~cm}$ \\
\hline $\begin{array}{l}\text { Hormone deficiency at } \\
\text { diagnosis }\end{array}$ & $\begin{array}{ll}\text { - } & \downarrow \text { FSH, LH, testosterone } \\
\text { - } & \downarrow \text { TSH, FT4 } \\
\text { - } & \downarrow \text { ACTH, basal cortisol }\end{array}$ & - $\downarrow$ FSH, LH, testosterone \\
\hline $\begin{array}{l}\text { Visual field testing at } \\
\text { diagnosis }\end{array}$ & $\begin{array}{l}\text { - } \text { right side temporal } \\
\text { quadrantanopsia } \\
\text { - left side temporal } \\
\text { hemianopsia. }\end{array}$ & Normal \\
\hline $\begin{array}{l}\text { Hormone deficiency at the } \\
\text { last check up }\end{array}$ & $\begin{array}{l}\text { persistent central } \\
\text { hypothyroidism. }\end{array}$ & $\begin{array}{l}\text { - persistent hypogonadotropic } \\
\text { hypogonadism. }\end{array}$ \\
\hline $\begin{array}{l}\text { Visual field testing at the } \\
\text { last check up }\end{array}$ & Normal & Normal \\
\hline Period of follow-up & 6 years and 6 months & 3 months \\
\hline
\end{tabular}
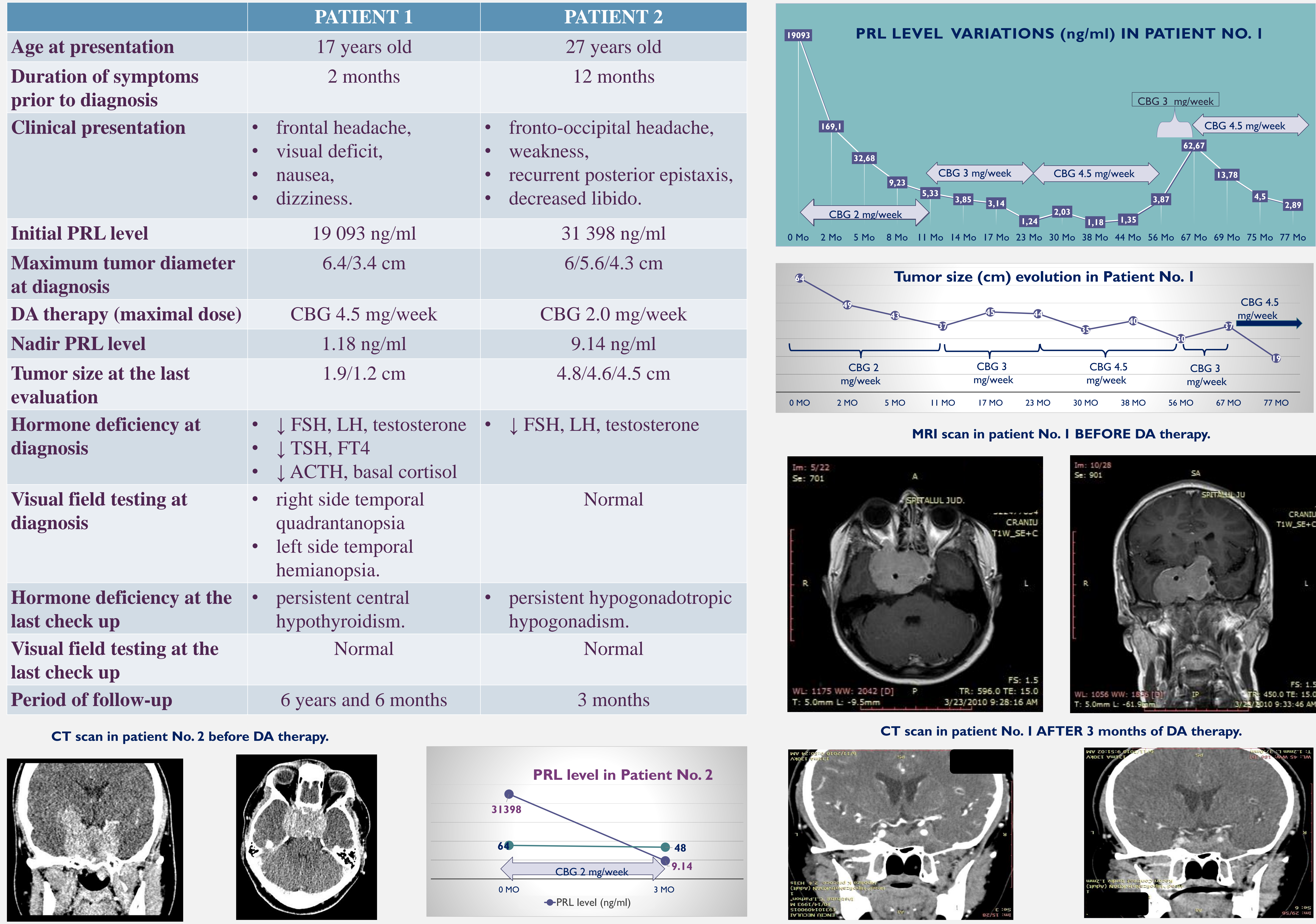

MRI scan in patient No. 2 AFTER 3 months of DA therapy.
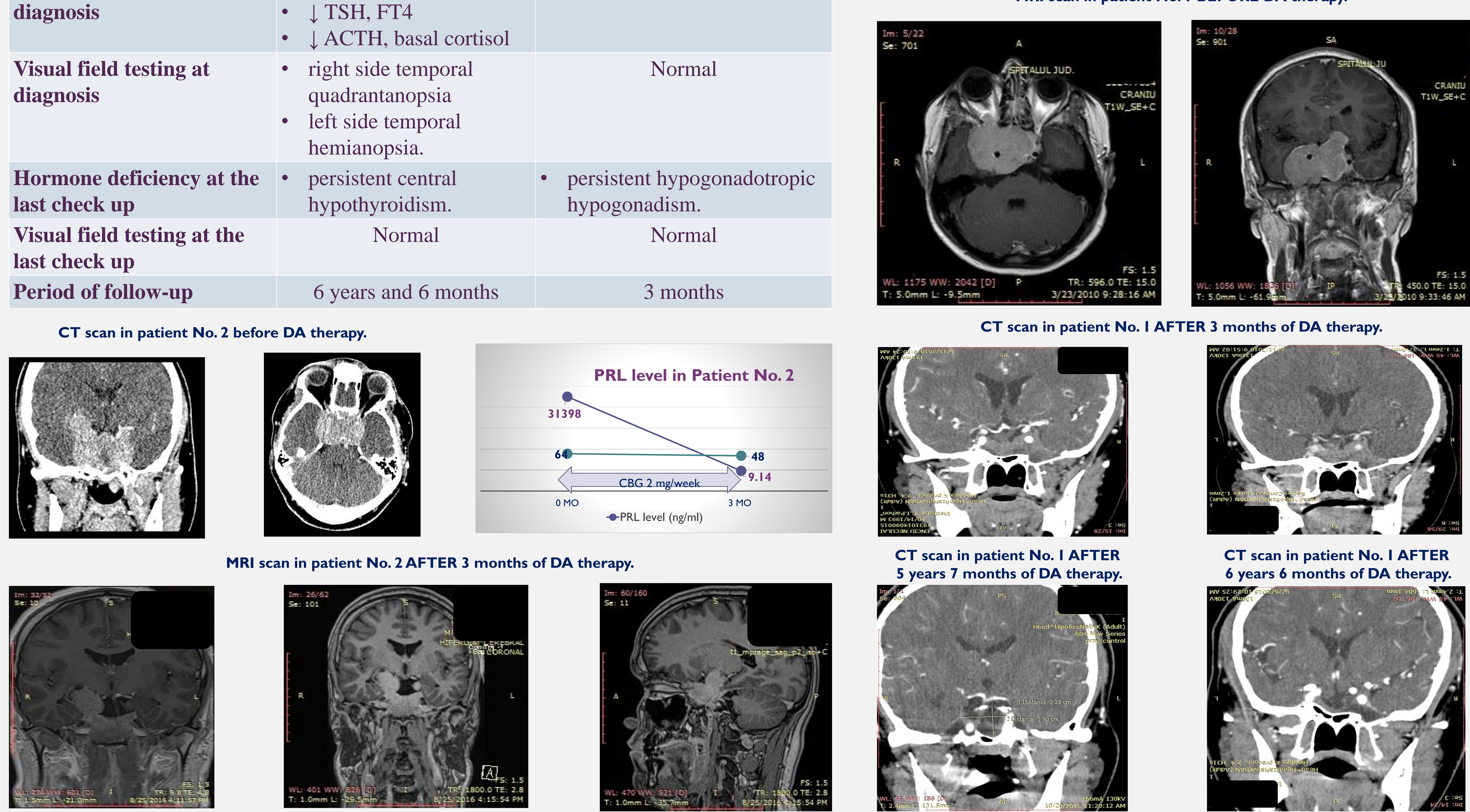

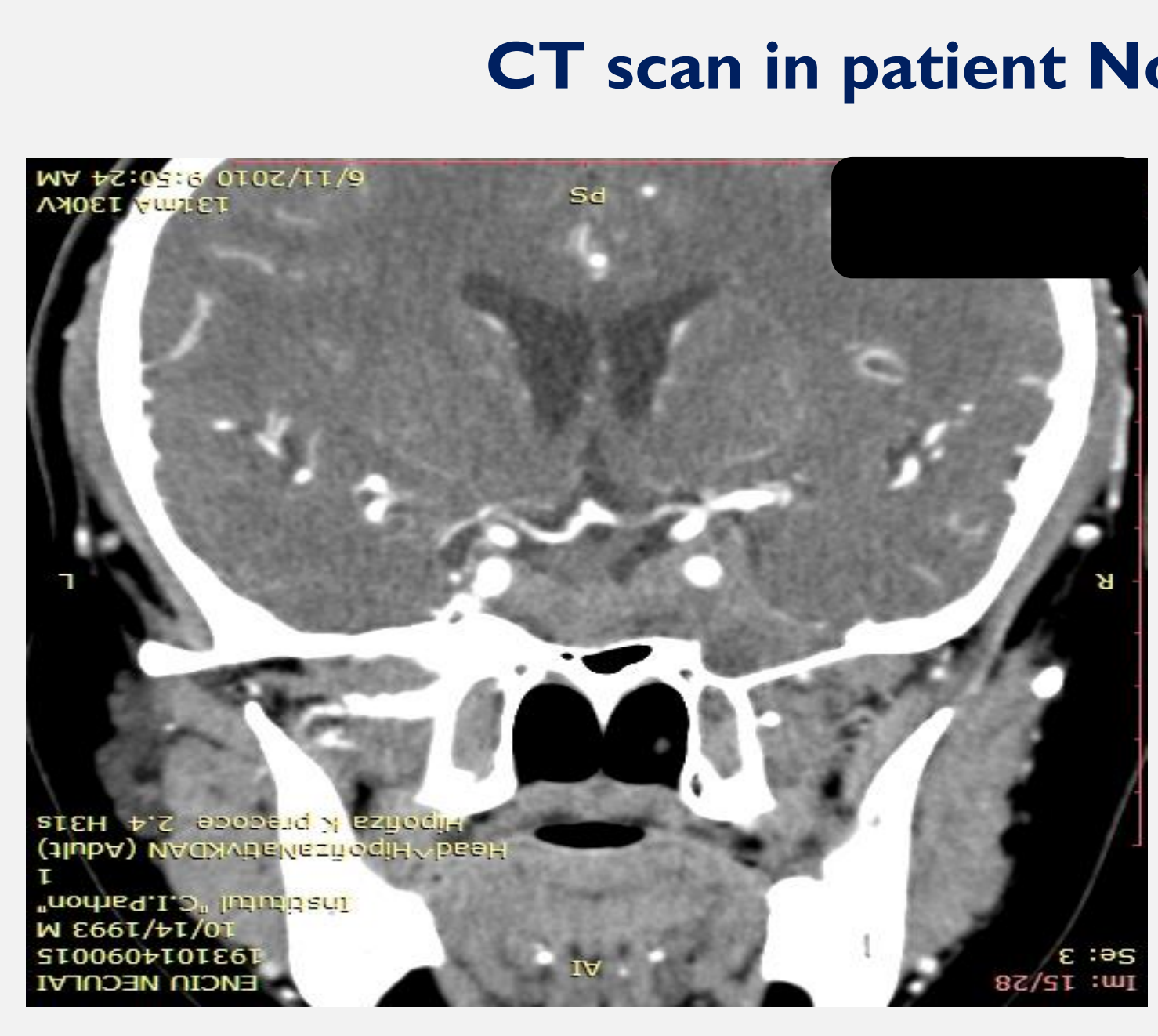

CT scan in patient No. I AFTER 5 years 7 months of DA therapy.

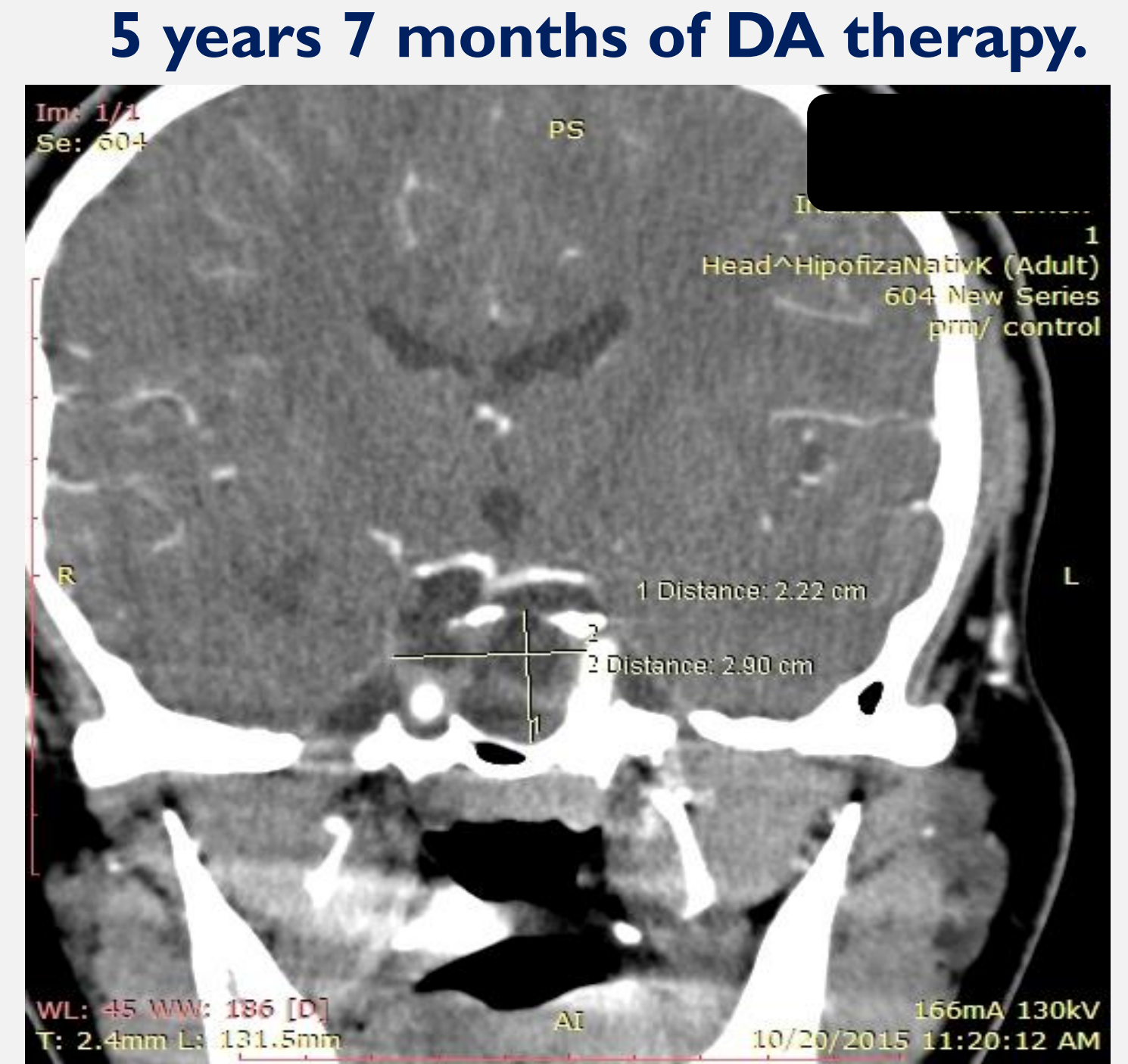

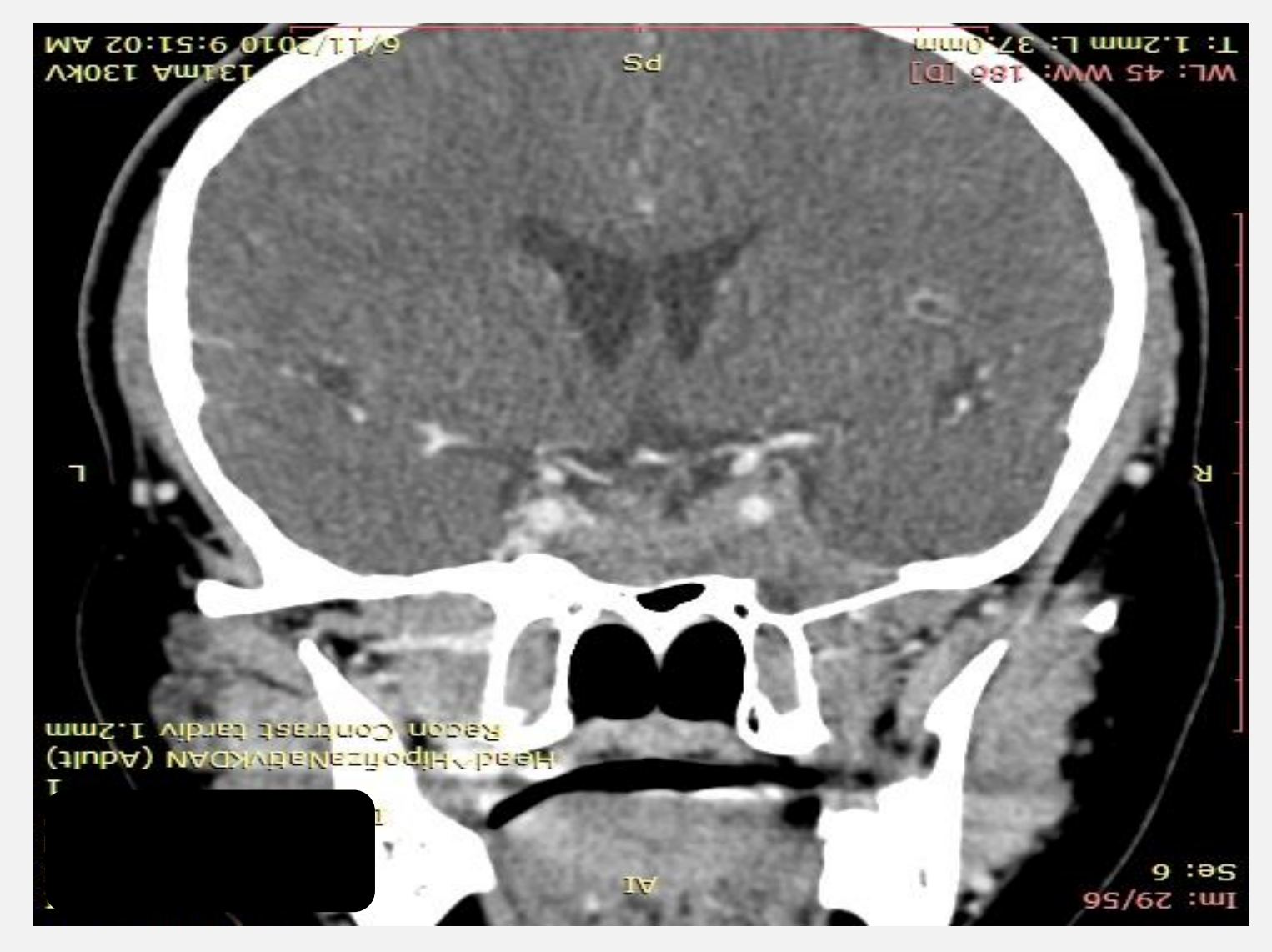

CT scan in patient No. I AFTER 6 years 6 months of DA therapy.

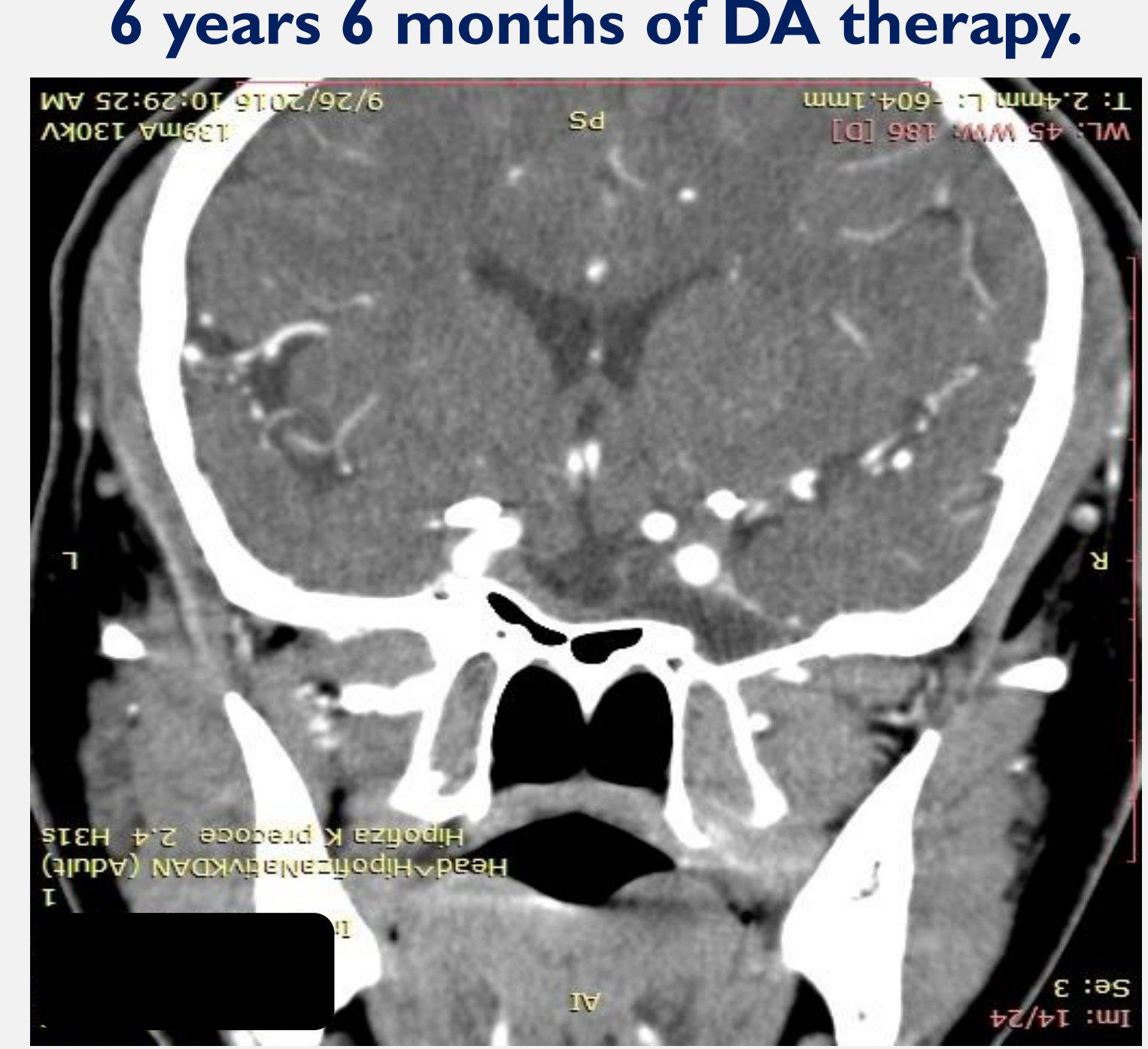

Conclusions: Despite the similar size and PRL values, giant prolactinomas in men can have a heterogeneous profile at diagnosis, from the classical visual field deficiency and pituitary failure to normal visual field and almost normal pituitary function. Correct diagnosis is capital to ensuring appropriate treatment. Various studies showed that most giant prolactinomas are less responsive to DA therapy, but in the two cases that we reviewed, improvement was seen in PRL normalization but also in size reduction. Lifelong follow-up is usually needed.

\section{Refferences:}

Delgrange, Etienne, et al. "Giant prolactinomas in women." European journal of endocrinology 170.1 (2014): 31-38.

Aljabri, Khalid S., Samia A. Bokhari, and Ahmad Akl. "Giant Prolactinoma: Case Report and Review of Literature."

et al. "Ten-year follow-up of a giant prolactinoma." BMJ case reports 2015 (2015): bcr2015212221.

Carlos Benbassat, and Moshe Hadani. "Effectiveness of long-term cabergoline treatment for giant prolactinoma: study of 12 men." European Journal of Endocrinology 156.2 (2007): $225-231$.

Maiter, Dominique, and Etienne Delgrange. "Therapy of endocrine disease: the challenges in managing giant prolactinomas." European Journal of Endocrinology 170.6 (2014): R213-R227. 